\title{
PENGARUH PELATIHAN DAN ETOS KERJA TERHADAP KINERJA DI DIVISIPDS DEPARTMENT PADA RUMAH SAKIT OMNI ALAM SUTERA TANGERANG SELATAN
}

\author{
Anas Nuruzzaman \\ Fakultas Ekonomi dan Bisnis, ITB Ahmad Dahlan Jakarta \\ Email: anas.nuruzzaman@gmail.com
}

\begin{abstract}
Abstrak
Tujuan penelitian ini adalah menganalisis Pengaruh Pelatihan dan Etos Kerja Terhadap Kinerja Karyawan di Divisi PDS Department pada Rumah Sakit Omni Internasional Alam Sutera Tangerang Selatan, yang beralamat di Jl.Alam Sutera Boulevard No.Kav 25,Pakulonan ,Kecamatan Serpong Utara,Kota Tangerang Selatan, Banten 15325. Desain penelitian ini menggunakan metode deskriptif asosiatif kuantitatif, teknik pengumpulan data penelitian kepustakaan (Library research) dan penelitian lapangan (field Research). Jumlah sampel yang digunakan penulis sebanyak 48 responden, terdiri dari karyawan divisi PDS dan teknik analisis data yang digunakan dalam penelitian ini ialah analisis uji instrumen data, asumsi klasik, uji regregsi linier berganda, uji korelasi, uji determinasi, uji t dan uji f dengan menguji variabel Pelatihan $\left(\mathrm{X}_{1}\right)$, Etos Kerja $\left(\mathrm{X}_{2}\right)$ dan Kinerja $(\mathrm{Y})$. Dari hasil penelitian uji $\mathrm{t}$ variabel Pelatihan $\left(\mathrm{X}_{1}\right)$ terhadap Kinerja $(\mathrm{Y})$ diperoleh nilai thitung $(12.938>0,442)$, hasil uji t variabel Etos Kerja $\left(\mathrm{X}_{2}\right)$ terhadap kinerja karyawan $(\mathrm{Y})$ diperoleh $\mathrm{t}_{\text {hitung }}$ $(3,767>0,442)$, sehingga dapat dinyatakan bahwa variabel pelatihan $\left(\mathrm{X}_{1}\right)$ berpengaruh sigifikan secara parsial terhadap kinerja $(\mathrm{Y})$ dan variabel etos kerja $\left(\mathrm{X}_{2}\right)$ berpengaruh signifikan secara parsial terhadap kinerja $(\mathrm{Y})$. Hasil uji f variabel Pelatihan $\left(\mathrm{X}_{1}\right)$ dan varibel Etos Kerja $\left(\mathrm{X}_{2}\right)$ diperoleh nilai $\mathrm{f}_{\text {hitung }}(154.484>3,37)$ sehingga dapat dinyatakan bahwa variabel Pelatihan $\left(\mathrm{X}_{1}\right)$ dan varibel Etos Kerja $\left(\mathrm{X}_{2}\right)$ berpengaruh signifikan secara simultan terhadap variabel Kinerja (Y). Hasil uji korelasi didapat nilai korelasi Pelatihan $\left(\mathrm{X}_{1}\right)$ 0,913, yang berarti pengaruh variabel tersebut bersifat kuat sedangkan Etos Kerja $\left(\mathrm{X}_{2}\right)$ 0,632 yang berarti pengaruh variabel tersebut bersifat kuat dan setelah dianalisa dengan menggunakan analisis koefisien determinasi $\left(\mathrm{R}^{2}\right)$ diperoleh hasil sebesar 0,873 $(87,3 \%)$ sehingga dapat disimpulkan bahwa variabel Pelatihan $\left(\mathrm{X}_{1}\right)$ dan Etos Kerja $\left(\mathrm{X}_{2}\right)$ berpengaruh sebesar 87,3\% terhadap kinerja karyawan (Y) sedangkan sisanya 12,7\% dipengaruhi faktor lain. ${ }^{9}$
\end{abstract}

Kata Kunci: Pelatihan, Etos Kerja, dan Kinerja.

\begin{abstract}
The purpose of this study was to analyze the effect of training and work ethic on employee performance in the PDS Department Division at Omni International Hospital Alam Sutera - South Tangerang, which is located at Jl. Alam Sutera Boulevard No. Kav 25, Pakulonan, North Serpong District, South Tangerang City, Banten 1532. This research design uses quantitative associative descriptive methods, data collection techniques for library research and field research. The number of samples used by the author is 48 respondents, consisting of employees of the PDS division and the data analysis techniques used in this study using data instrument test analysis, classical assumptions, multiple linear regression test, correlation test, determination test, $t$ test and f test by testing variablesof training (X1), work ethic (X2), and performance $(Y)$. From the results of the t-test of the training variable (X1) on performance $(Y)$, the t-test value (12.938>0.442), the results of the t-test of the work ethic variable (X2) on employee performance (Y) obtained tcount (3.767>0.442), so it can be stated that the training variable (X1) has a partially significant effect on performance (Y) and the work ethicvariable (X2) has a partially significant effect on performance $(Y)$. The results of the f-test of the training variable $(X 1)$ and the work ethic variable (X2) obtained the fcount value (154.484 >3.37) so that it can be stated that the training variable (X1) and the work ethic variable (X2) simultaneously have a significant effect on the performance variable $(Y)$. The results of the correlation test obtained that the training
\end{abstract}


correlation value (X1) was 0.913, which means the influence of the variable is strong while the work ethic (X2) is 0.632, which means the influence of the variable is strong and after being analyzed using the coefficient of determination analysis (R2), the result is $0.873(87) ., 3 \%)$ so that it can be concluded that the variable training (X1) and word ethic (X2) has an effect of $87.3 \%$ on employee performance (Y) while the remaining $12.7 \%$ is influenced by other factors.

\section{Keywords: Training, Work Ethic and Performance}

\section{PENDAHULUAN}

Sebuah organisasi untuk mewujudkan eksistensinya dalam rangka mencapai tujuan memerlukan perencanaan sumber daya manusia yang efektif. Suatu organisasi , tanpa didukung oleh karyawan atau pegawai yang sesuai baik segi kuantitatif atau kualitatif, strategi dan operasionalnya, maka organisasi atau perusahaan itu tidak akan mampu mempertahankan keberadaannya, mengembangkan dan memajukan di masa yang akan datang. Oleh karena itu disini diperlukan adanya langkah- langkah manajemen guna lebih menjamin bahwa organisasi tersedia tenaga kerja yang tepat untuk menduduki berbagai jabatan, fungsi pekerjaan yang sesuai kebutuhan perusahaan.

Dalam suatu organisasi kegiatan peranan manajemen sangat dibutuhkan sebab, Manajemen adalah suatu keharusan yang dimiliki oleh suatu perusahaan untuk mengatur SDM di dalamnya. Tanpa adanya Manajemen SDM didalamnya semua operasional yang ada di perusahan tidak akan berjalan dengan baik, yang akan berdampak pada tujuan perusahaan yang sulit untuk terelisasi.

Perkembangan dunia usaha dan industri di era globalisasi saat ini membuat semua lapisan masyarakat paham akan pentingnya suatu pendidikan sebagai salah satu kebutuhan disamping kebutuhan hidup yang lainnya. Kemajuan teknologi dan informasi tidak lepas oleh peranan pendidikan di kalangan masyarakat. Faktor -faktor yang perlu diperhatikan untuk meningkatkan tingkat individu ialah dari segi tingkat pendidikan. Setiap karyawan memiliki latar belakang pendidikan yang beragam semakin tinggi tingkat suatu pendidikan seorang karyawan, diharapkan semakin baik juga dalam mengambil suatu keputusan dalam memecahkan suatu masalah.

Karena persaingan kerja yang sangat ketat, maka kita dituntut untuk memiliki etos kerja yang tinggi dan mulia. Karena di era globalisasai saat ini, perusahaan dituntut untuik mampu lebih profesional dengan membudayakan etos kerja yag tinggi. Kalau digambarkan lebih kecil kembali etos ini merupakan suatu sikap dari keseluruhan individu yang beragam.

Rumah sakit merupakan suatu organisasi padat karya (kegiatan pembangunan proyek lebih banyak menggunakan tenaga manusia dibandingkan dengan tenaga mesin) dimana didalamnya terdapat karyawan-karyawan dengan bidang yang berbeda yang bekerja demi mencapai suatu tujuan organisasi. Rumah Sakit Omni adalah suatu rumah sakit yang maju dan berkembang, sehingga membutuhkan SDM yang tangguh dan tanggap untuk mendukung kegiatan pemberian pelayanan kesehatan yang terbaik kepada pasien, baik itu kegiatan Medis maupun Non Medis.

Salah satu kunci utama dalam menciptakan SDM yang profesional terletak pada proses penerimaan karyawan, seleksi, pelatihan dan pengembangan sumber daya yang ada didalamnya. Rumah sakit membutuhkan cukup banyak SDM dengan berbagai keterampilan dan orang yang kompeten untuk mencapai visi dan misi rumah sakit serta memenuhi tuntutan kebutuhan keamanan dan keselamatan pasien.

Peneliti melakukan observasi awal di Patient and Doctor Services Department (PDS Department), Rumah Sakit Omni Internasional Alam Sutera Tangerang Selatan, dengan hasil tampak masih terdapat beberapa karyawan yang kinerjanya menurun, dimana tidak tercapainya kuantitas pekerjaan, dan penyelesaian pekerjaan sering kali terjadi kesalahan sehingga tidak sesuai tugas dan tanggungjawabnya.

Dalam melaksanakan suatu operasional pekerjaan di PDS Department, permasalahan lain terkait dengan pelatihan, dimana program pelatihan dan pengembangan SDM karyawan Rumah Sakit Omni Alam Sutera Tangerang Selatan masih belum dapat meningkatkan keahlian maupun kemampuan, kerja karyawan, dimana karyawan baru tidak mendapatkan pelatihan secara langsung namun harus menunggu beberapa bulan terlebih dahulu sehingga dapat memperlambat dalam penyelesaian pekerjaan dikarenakan belum ada pengalaman dan metode pelatihan yang ditawarkan monoton sehingga 
menimbulkan ketidaktertarikan atau karyawan menjadi tidak ada kemauan dalam peningkatan kemampuan.

Begitu juga dengan etos kerja karyawan pada PDS Departement yang menurun kualitasnya, tampak terdapat beberapa karyawan yang kurang disiplin dalam waktu kehadiran dengan berbagai alasan pribadi diantaranya kegiatan hingga tengah malam, tempat tinggal yang jauh dan masalah keluarga sehingga terlambat absen kerja, kemudian rasa tanggung jawab dan kepedulian terhadap pekerjaan menurun dengan alasan pergantian jam kerja menyebabkan kondisi fisik lelah sehingga sering melakukan kesalahan pada saat serah terima tugas harian. Kondisi tersebut berdampak pada departement lain yang berhubungan dengan PDS Departement. Selain itu karyawan pada PDS Departement dalam melaksanakan tugasnya sekedar menjalankan saja sesuai job desk saja, tidak ada kemauan untuk peningkatan kemampuan diri, tekun bekerja menurun. Rendahnya etos kerja karyawan pegawai pada PDS Departement disebabkan adanya pemikiran dimana bekerja itu untuk mendapatkan uang saja, tanpa adanya kontribusi dari diri karyawan untuk kemajuan organisasi.

\section{Pernyataan untuk variabel pelatihan}

\begin{tabular}{|c|c|c|}
\hline No & Pernyataan & Bobo \\
\hline 1 & $\begin{array}{l}\text { Instruktur ahli dalam menyampaikan materi } \\
\text { saat pelatihan }\end{array}$ & 185 \\
\hline 2 & $\begin{array}{l}\text { Instruktur menguasai materi pelatihan sehingga } \\
\text { mampu menjelaskan materi dengan baik }\end{array}$ & 178 \\
\hline 3 & $\begin{array}{l}\text { Anda selalu bersemangat untuk mengikuti } \\
\text { pelatihan }\end{array}$ & 186 \\
\hline 4 & $\begin{array}{l}\text { Anda mengikuti pelatihan berdasarkan } \\
\text { kesesuaian jabatan. }\end{array}$ & 178 \\
\hline 5 & $\begin{array}{l}\text { Metode penyajian dalam pelatihan telah sesuai } \\
\text { dengan jenis pelatihan yang dibutuhkan peserta } \\
\text { pelatihan. }\end{array}$ & 174 \\
\hline 6 & $\begin{array}{l}\text { Metode pelatihan dipilih sesuai dengan jabatan } \\
\text { dan posisi karyawan }\end{array}$ & 183 \\
\hline 7 & $\begin{array}{l}\text { Materi pelatihan sesuai dengan kebutuhan } \\
\text { anda,sehingga mampu menunjang pekerjaan } \\
\text { yang anda lakukan }\end{array}$ & 183 \\
\hline 8 & $\begin{array}{l}\text { Materi yang diberikan lengkap dan dapat } \\
\text { dengan mudah dipahami }\end{array}$ & 132 \\
\hline 9 & $\begin{array}{l}\text { Setelah mengikuti pelatihan,anda mampu } \\
\text { menyelesaikan pekerjaan dengan lebih mudah } \\
\text { dan cepat }\end{array}$ & 179 \\
\hline
\end{tabular}




\begin{tabular}{|c|l|c|}
\hline $\mathbf{1 0}$ & $\begin{array}{l}\text { Pelatihan yang diselenggarakan mempunyai } \\
\text { sasaran yang jelas dan bermanfaat }\end{array}$ & 186 \\
\hline \multicolumn{2}{|c|}{ Jumlah Total } & $\mathbf{1 . 8 0 8}$ \\
\hline
\end{tabular}

Berdasarkan data diatas dapat dilihat bahwa total jawaban tertinggi sebesar 186 dengan pernyataan"Pelatihan yang diselenggarakan mempunyai sasaran yang jelas dan bermanfaat" hal ini menunjukan bahwa penyelenggaran sebuah pelatihan mempunyai tujuan yang bisa mengembangkan kinerja karyawan. Sedangkan total jawaban terendah sebesar 132 dengan pernyataan "Materi yang diberikan lengkap dan dapat dengan mudah dipahami" hal ini menujukan bahwa materi yang diberikan oleh Instruktur sulit untuk dipahami oleh peserta pelatihan.

Pernyataan untuk variabel etos kerja

\begin{tabular}{|c|l|c|}
\hline No & \multicolumn{1}{|c|}{ Pernyataan } & Bobot \\
\hline $\mathbf{1}$ & Saya selalu melakukan pekerjaan dengan penuh kejujuran & 194 \\
\hline $\mathbf{2}$ & Saya harus bekerja dengan penuh intergitas & 176 \\
\hline $\mathbf{3}$ & $\begin{array}{l}\text { Saya selalu bersyukur dalam melakukan tugas dan tanggung } \\
\text { jawab }\end{array}$ & 190 \\
\hline $\mathbf{4}$ & Saya sangat beruntung bisa diposisi kerja saat ini & 187 \\
\hline $\mathbf{5}$ & Saya akan melakukan pekerjaan dengan suka cita & 176 \\
\hline $\mathbf{6}$ & Saya harus melakukan pekerjaan dengan tekun & 181 \\
\hline $\mathbf{7}$ & $\begin{array}{l}\text { Saya harus melakukan pekerjaan dengan serius dan penuh } \\
\text { pengabdian }\end{array}$ & 191 \\
\hline $\mathbf{8}$ & Saya dapat melakukan pekerjaan dengan tuntas & 188 \\
\hline & Jumlah Total & $\mathbf{1 . 4 8 1}$ \\
\hline
\end{tabular}

Berdasarakan data diatas dapat dilihat bahwatotal jawaban tertinggi sebesar 194 dengan pernyataan "Saya selalu melakukan pekerjaan dengan penuh kejujuran" hal inimenunjukan bahwa kejujuran merupakan sifat utama yang dirasa oleh karyawan,sebab bekerja didalam industri kesehatan kejujuran sangat di junjung tinggi karena bersangkutaan dengan kondisi pasien. Sedangkan total terendah sebesar 176 dengan pernyataan "Saya akan melakukan pekerjaan dengan suka cita " hal ini menunjukan bahwa rasa suka cita terhadap pekerjaan dan tanggung jawab karyawan masih rendah, bisa disebabkan oleh bebrapa faktor antara lain adalah tingkat stres dari atasan dan pasien yang membuat kinerja karyawan menurun. 


\section{Pernyataan untuk variabel kinerja}

\begin{tabular}{|c|c|c|}
\hline No & Pernyataan & Bobot \\
\hline 1 & $\begin{array}{l}\text { Hasil pekerjaan sudah sesuai dengan harapan dan } \\
\text { organisasi }\end{array}$ & 200 \\
\hline 2 & $\begin{array}{l}\text { Saya dapat menyelesaikan pekerjaan lebih cepat } \\
\text { dari target yang telah ditentukan }\end{array}$ & 193 \\
\hline 3 & $\begin{array}{l}\text { Semakin bertambah usia saya ,semakin } \\
\text { meningkat juga kualitas pekerjaan saya }\end{array}$ & 195 \\
\hline 4 & Saya sangat disiplin dalam bekerja & 199 \\
\hline 5 & $\begin{array}{l}\text { Saya selalu berusaha mempernbaiki kesalahan } \\
\text { pekerjaan yang pernah saya lakukan dalam } \\
\text { melaksanakan pekerjaan }\end{array}$ & 184 \\
\hline 6 & $\begin{array}{l}\text { Saya memiliki kemempuan yang baik dalam } \\
\text { menyelesaikan pekerjaan yang dibebankan } \\
\text { kepada saya }\end{array}$ & 189 \\
\hline 7 & $\begin{array}{l}\text { Saya mendapatkan tim kerja yang saling } \\
\text { mendukung }\end{array}$ & 181 \\
\hline 8 & $\begin{array}{l}\text { Saya merasakan kerjasama antara atasan dan } \\
\text { bawahan berjalan dengan baik }\end{array}$ & 165 \\
\hline 9 & $\begin{array}{l}\text { Saya memiliki pengetahian atas pekerjaan yang } \\
\text { saya lakukan }\end{array}$ & 191 \\
\hline 10 & $\begin{array}{l}\text { Saya memiliki kepercayaan diri dan kemampuan } \\
\text { yang tinggi dlam mengambil keputusan yang } \\
\text { baik }\end{array}$ & 193 \\
\hline \multicolumn{2}{|c|}{ Jumlah Total } & 1.890 \\
\hline
\end{tabular}


Berdasarkan data diatas dapat dilihat total jawab tertinggi 148 dengan pernyataan "Saya dapat menyelesaikan pekerjaan lebih cepat dari target yang telah ditentukan" hal ini menunjukan tanggung jawab dan semnagat kerja karyawan untuk melaksanakan pekerjaanya terlihat dari bagaimana cara menyelesaikan pekerjaan dan target waktu yang diberikan. Sedangakan nilai terendah adalah 130 dengan pernyataan "Saya merasakan kerjasama antara atasan dan bawahan berjalan dengan baik " hal ini menunjukan ketidak harmonisan antara atasan dan bawahan dalam divisi ini , sehingga mengakibatkan kinerja karyawan menurun.

Berdasarkan permasalahan diatas peneliti tertarik untuk mengkaji dan melakukan penelitian pada Rumah Sakit Omni Alam Sutera Tangerang Selatan, khususnya pada PDS Departement dengan judul "Pengaruh pelatihan dan etos kerja terhadap kinerja karyawan PDS Department Rumah Sakit Omni Internasional Alam Sutera Tangerang Selatan”.

\section{METODE PENELITIAN}

Penelitian didefinisikan oleh Sekaran dan Bougie (2010:2) sebagai suatu proses sederhana untuk menemukan berbagai solusi dari suatu masalah setleah melalui proses studi dan analisisterhadap berbagai faktor situasional. Dalam melakukan penelitian ini penulis menggunakan metode deskriptif asosiatif kuantitatif.

Sudjana (2005:03) mendefisinikan statistika sebagai pengertian yang berhubungan dengancaracara pengumpulan data pengolahan, penganalisaan dan penarikan kesimpulan berdasarkan kumpulan dan penganalisaan data yang telah dilakukan. Sedangkan menurut Anas Sudjiono (2017:29), Statistika sebagai ilmu pengetahuan yang mempelajari dan mengembangkan secara ilmiah,tahap-tahap yang ada dalam kegiatan statistik.

Sujarweni (2015:39) mengatakan statistik deskriptif adalah sesuatu yang menggambarkan berbagai karakteristik data yang berasal dari suatu sampel. Sedangkan menurut Bryman dalam Sujarweni (2015:39) proses penelitian kuantitatif dimulai dari teori, hipotesis, desain penelitian, memilih subjek, mengumpulkan data, memproses data, menganalisa data dan menuliskan kesimpulan.

Sementara itu menurut Sujawerni (2015:49) penelitaian kuantitatif asosiatif merupakan penelitian yang bertujuan untuk mengetahui hubungan antara dua variabel atau lebih.

Berdasarkan pada metode deskriptif asosiatif kuantitatif,peneliti ingin mengetahui hubungan atau pengaruh antara pelatihan $\left(\mathrm{X}^{1}\right)$ dan etos kerja $\left(\mathrm{X}^{2}\right)$ terhadap kinerja $(\mathrm{Y})$ yang merupakan variabelvariabel yang akan diteliti.

A. Objek Penelitian

Objek dalam peneleitian ini adalah Staf di divisi PDS Department di Rumah Sakit Omni Internasional Alam Sutera,neralamat di Jalan Alam Sutera Kav.25,Pakulonan,Serpong Utara Tangerang Selatan, Banten. 15325.

B. Waktu Penelitian

Dalam melakukan penelitian ini,waktu yang dibutuhkan peneliti dari mulai pengajuan judul sampai sidang skripsi.

Variabel Penelitian

Menurut Sugiyono dan Sujarweni (2015:75) variabel penelitian adalah suatu hal yang berbentuk apa saja yang ditetapkan oleh peneliti untuk di pelajari sehingga diperoleh informasi tentang hal tersebut 
dan kemudian ditarik kesimpulannya.

Adapun variabel dalam penelelitian ini terdiri:

1.Variabel Bebas (Independent) yaitu variabel yang mempengaruhi variabel terkait baik itu secara positif ataupun negatif,serta sifatnya berdiri sendiri. Dalam penelitian ini yang menjadi variabel bebas adalah Pelatihan (X1) dan Etos Kerja (X2)

2.Variabel Terkait (dependent), variabel yang dipengaruhi oleh variabel bebas yang sifatnya tidak dapat berdiri sendiri serta menjadiu perhatian utama peneliti. Variabel terkait dalam penelitian ini adalah kinerja karyawan $(\mathrm{Y})$.

\section{HASIL DAN PEMBAHASAN}

Pembahasan ini menggunakan tiga variabel, yaitu Pelatihan sebagai (X1), Etos Kerja sebagai (X2) yang menjadi variabel independen (bebas) dan kinerja karyawan sebagai ( $\mathrm{Y}$ ) yang menjadi variabel dependen (terikat). Dalam penelitian ini menggunakan data primer dari penyebaran kuisioner dengan jumlah sampel sebaanyak 48 responden pada Rumah Sakit Omni Internasional Alam Sutera- Tangerang Selatan, masingmasing kuisioner terdiri dari 10 item pernyataan untuk variablel X1 , 8 item pernyataan untuk variabel X2 dan variabel (Y) sebanyak 10 item pernyataan. Semua pernyataan kuisioner tersebut adalah valid, reliabel dan normal.

\section{KESIMPULAN DAN SARAN}

Variabel $\mathrm{X}^{1}$ (pelatihan) dan variabel $\mathrm{X}^{2}$ (etos kerja) secara simultan mempunyai pengaruh yang signifikan terhadap Kinerja di Divisi PDS Department, terlihat $F_{\text {hitung }}$ ( 154.484 ) $>F_{\text {tabel }}$ ( 2.279 ) yang berarti Pelatihan dan Etos Kerja mempunyai andil dalam mempengaruhi kinerja di Divisi PDS Department Rumah Sakit Omni Internasional Alam Sutrea- Tangerang Selatan. ${ }^{6364}$

\section{REFERENSI}

Edison, Emron dkk. 2018. Manajemen Sumber Daya Manusia. Bandung. Alfabeta

Ghazali, Imam. 2016. Aplikasi Analisis Multivariete Dengan Program IBM SPSS 23.

Semarang:Undip.

Hasibuan, Malayu. 2017. Manajemen Dasar, Pengertian Dan Masalah. Jakarta. Bumiaksara.

Simamora, Henry. 2015. Manajemen Sumber Daya Manusia Edisi III.Yogyakarta: STIE YKPN

Sinamo dan Novialdi ,2016. 8 Etos Kerja Profesional. Semarang. Jaya Abadi Sentosa. 